\title{
Paradox of Social Capital in the Implementation of Public Policy (Finding in the Tanimbar Islands Regency) ${ }^{1}$
}

\author{
Nikolaus Powell Reressy ${ }^{2}$ \\ Agus Pramusinto 3 \\ Subando Agus Margono ${ }^{4}$ \\ Ely Susanto ${ }^{5}$
}

\begin{abstract}
The era of decentralization (autonomization) has begun in Indonesia since 1999. Various public policies have been made to support the implementation of decentralization. Of the many public policies, there are those that have been successfully implemented, but not a few have experienced ineffectiveness to failure. Many studies reveal that social capital is one of the factors that supports the successful implementation of various public policies. However, there is still very little research that looks at the dark side (paradox) of social capital, which contributes to the ineffectiveness of the implementation of a public policy. This paper discusses the paradox of social capital that causes the ineffectiveness of the process of implementing a public policy. The various cases discussed in this paper show that local government as implementing institution face serious obstacles in implementing various public policies, when public policies collide with the values of social capital that are lived and trusted by the local community. The Tanimbar Islands are a small and poor regency in Maluku Province, which also experiences this problematic situation. This situation occurs when the applied public policies clash with reality regarding some forms (manifestations) of social capital found in the community, such as the cultural values of duan lolat, sweri practices, and communal lifestyles in tnyafar. By showing the case of the Tanimbar Islands, we can see the dark side of social capital in the implementation of public policies, which in the future, need to be resolved.
\end{abstract}

\section{Keywords:}

Implementation of public policy; paradox of social capital; duan lolat; sweri; tnyafar

\section{Introduction}

Studies of social capital in relation to the implementation of development have been carried out. Geertz (1989) states that social capital has a very important contribution to the implementation of development. He pointed to the value of mutual cooperation adopted by the people in Java as one form

\footnotetext{
${ }^{1}$ This paper is extracted from dissertation research conducted by the First Author at the Department of Public Policy and Management, Faculty of Social and Political Science, Universitas Gadjah Mada. In that study, the Second Author, Third Author and Fourth Author were supervisors.

2 The Division of Governance, Regional Secretary, Tanimbar Islands Regency Government

${ }^{3}$ Department of Public Policy and Management, Faculty of Social and Political Science, Universitas Gadjah Mada

${ }^{4}$ Department of Public Policy and Management, Faculty of Social and Political Science, Universitas Gadjah Mada

${ }^{5}$ Department of Public Policy and Management, Faculty of Social and Political Science, Universitas Gadjah Mada
} 
of social capital that strongly supports the implementation of development in Indonesia. Coleman (1990), in his research on youth and education in American schools, also found that social capital owned by a community entity can contribute positively to the implementation of education policy. Coleman's thesis through this research made an important contribution to efforts to achieve racial equality in America. World Bank $(1998 ; 2006)$ also found that social capital has played a positive role in education, health services and the provision of public infrastructure in various countries.

In Indonesia, since the implementation of the era of decentralization in 1999, the attention of researchers to the issue of social capital and its relation to the implementation of development has been increasing. Some of them are Nurhadi (2000), who stated that social capital strongly supports the development of community forests in Kedungkeris Village, Ngipar District, Gunung Kidul Regency. Senoaji (2004) states that social capital has an important contribution in the use of forests and the environment by the Baduy community in South Banten. Sulastriyono (2008; 2009) states that social capital has been used as a basis in the development of the Law of River Water Resources in Indonesia. Sahlan (2009) states that the social capital of the Tau Taa Wana Bulang community has an important contribution in efforts to conserve forests in Central Selawesi Province. Asmara, Arba, and Maladi (2010) state that social capital has an important role in efforts to resolve land conflicts in East Nusa Tenggara. Mulyadi (2010) states that social capital is an important factor in the management of agricultural land in Soppeng Regency. Ruslanjari (2010) states that social capital has played an important role in the rehabilitation and reconstruction of earthquake disasters in Bantul Regency. Kusumasari (2014) also reported the use of local wisdom and social capital in the disaster recovery process in Bantul Regency due to a tectonic earthquake in Yogyakarta in 2006. ${ }^{6}$ Previously, Susanto and Rostiani (2012) also reported how expatriate social capital and emotional intelligence could function as variables in an effort to increase cost effectiveness in cross-cultural training for expatriates. Cross-cultural training itself has been believed to contribute positively to the process of adjusting expatriates.

The researchers above examined the positive side of social capital in development, both in the implementation of a public policy, and in the governance and development of an organization. On the contrary, there are still a few people who highlight the negative aspects of social capital, which in turn has hampered the implementation of development, especially in the implementation of a public policy. In a paper entitled "Social Capital: The Good, the Bad, and the Ugly", Adler and Kwon (2000, p. 106), for example, mention that:

"However, social capital sometimes can be profoundly dysfunctional and counter-productive. As with physical capital, investment in social capital are not costlessly reversible or convertible, and therefore unbalances investment or overinverstment in social capital can transform a potentially productive asset into a constraint and a liability."

In other words, in situations where there is an imbalance in the investment of social capital, social capital itself will be dysfunctional. In the context of development, the existence of dysfunctional social capital such as this will be counterproductive to development goals.

The research that is considered the closest to this research is the research conducted by Portes (1998, in Graeff, 2009, p. 146-147) which shows an example of the negative side of social capital, namely when social control over the actors gathered in it is too strong. By referring to the research conducted by Waldinger under the

\footnotetext{
${ }^{6}$ See also the elaboration in Margono and Kusumasari (2014, p. 64-91).
} 
title "The Other Side of Embeddeness: A Case Study of the Interplay Between Economy and Ethnicity", published in 1995, Portes stated that the social controls carried out internally within the immigrant group were so strong that the immigrants actually became more exclusive. This condition has a relatively negative impact on social relations that the immigrants wake up with other people who are not part of the group (non-members).

Portes (1998) as cited in Adler and Kwon (2000, p. 106-107) with reference to the research carried by Uzzi entitled "Social Structure and Competition in Interfirm Networks: The Paradox of Embeddedness", published in 1997, also shows others manifestation of the dark side of capital, where social capital has the potential to create free riding problems and become an obstacle to a business venture (hinder entrepreneurship).

In line with the opinions of Adler and Kwon, and the Portes above, this paper also wants to provide a proposition that social capital does not always make a positive contribution to the implementation of development. This paper will highlight some negative aspects of social capital, especially those related to the implementation of public policy. To sharpen the discussion, the discussion will be directed at the symptoms of the ineffectiveness of poverty reduction policies in Tanimbar Islands Regency which try to be associated with the phenomenon of ekslusivism which occurs in the cultural values of duan lolat as the highest customary law in the Tanimbar community, sweri practices, and communal life patterns in tnyafar.

\section{Regional Autonomy and Public Policy}

Litvack, Ahmad, and Bird (1998, p. 4) suggest that the decentralization agenda implemented in many countries is an implication of the implementation of broad reforms in the political and economic sectors in these countries. In line with that, the era of decentralization (autonomization) currently taking place in Indonesia can also be said to be a result of the implementation of fundamental reforms in the political and economic fields in 1998.

Theimplementation of regional autonomy in Indonesia with the enactment of Law No. 22 of 1999 concerning Regional Government ${ }^{7}$ also simultaneously responded to the paradigm shift in the implementation of development which is rampant in many countries at the beginning of the 21st century. If previously the development was carried out by using the supply driven development paradigm ${ }^{8}$ with a top-down or technocratic mechanism, then development is currently carried out by using the paradigm of demand driven development with a bottom-up or participatory mechanism. ${ }^{9}$

In the perspective of public policy we can use the opinion of Litvack, Ahmad, and Bird (1998, p. 6) above which further explains that the implications of implementing the decentralization agenda lie in the distribution of fiscal, political and administrative power. These three types of power (fiscal, political, and administrative) which were previously concentrated in the central government, are obliged to be distributed at certain limits to the regional government. That means, public policy makers in each region have the opportunity to

\footnotetext{
${ }^{7}$ Amended by Law No. 32/2004, Law No. 8/2005, Law No. 12/ 2008, and finally by Law No. 23/2014.

${ }^{8}$ The term "paradigm" used in this paper is intended to emphasize the way of view (imagination) that is used to see a development process.

${ }^{9}$ As stated above, the term "supply-driven development" used in this paper refers to the top down development approach, while the term "demand-driven development" refers to the bottom up development approach. The two terms above are commonly used by previous writers to describe a development process. See for example Litvack, Ahmad, and Bird (1998, p. 28) who use the term "supply-driven" to describe the top down approach in the development process, and the term "demanddriven" to explain the bottom up approach in the development process. Also see the Center for Strategic and International Studies (2017) which more fully uses the term "demand driven development" to explain the bottom up approach in the development process.
} 
make policies that are expected to be able to respond to the needs of their respective regions.

Public policy itself is a government provision that is made to respond to issues of a public nature, namely overcoming various social problems or meeting the needs of many people. In the context of this research, the intended public policy is public policy that is expected to be able to overcome substantial problems in the community, such as the problem of poverty. According to Anderson (1990, p. 15):

Substantive policies are concerned with governmental action to deal with substantive problems, such as highway construction, environmental protection, or payment of welfare benefits.

In other words, substantial policy is a type of public policy that focuses on government activities or activities to solve basic problems, such as education, health, providing subsidies to underprivileged people, or building roads and irrigation, and so forth. Thus, it can be argued that substantial policies basically provide pressure on the subject matter of what is needed by citizens.

\section{Effectiveness of Public Policy Implementation: Social Environment Variables}

The success of public policy implementation is determined by many variables, and each of these variables is related to each other. Of the many variables, social environmental problems have received special attention. Donald S. van Meter and Carl E. van Horn (1975) stated that the variables of social, political, and economic conditions greatly influence the success of public policy implementation. They mentioned 5 (five) indicators related to this variable, namely: (i) environmental economic resources that can support the success of policy implementation, (ii) the extent to which interest groups provide support for policy implementation, (iii) the characteristics of partisans, namely, supporting or rejecting, (iv) how the nature of public opinion exists in the environment, and (v) whether the political elite supports the implementation of the policy.

In line with the above opinion, George C. Edwards III (1980) also stated that communication variables strongly influence the success of public policy implementation. The variable requires that the implementor know what to do. The policy goals and objectives must be transmitted to the target group so that it will reduce the distortion of implementation. If the goals and objectives of a policy are unclear or even not known at all by the target group, then there will be a possibility of resistance from the target group.

On another occasion, Merilee S. Grindle (1980) also stated that environmental policy variables greatly influence the implementation of public policy. This variable includes 3 (three) indicators, namely: (i) how much power, interest, and strategies are possessed by the actors involved in policy implementation, (ii) characteristics of the ruling institutions and regimes, and (iii) the level of compliance and responsiveness of the target group.

Daniel A. Mazmanian and Paul A. Sabatier (1983) also mention that environmental variables (nonstatutory variables affecting implementation) greatly influence the success of policy implementation. There are 4 (four) indicators contained in this variable, namely: (i) the socio-economic conditions of the community and the level of economic progress, (ii) public support for a policy, (iii) the attitude of the constituency groups, and (iv) the level of commitment and skills of the apparatus and implementers.

G. Shabbir Cheema and Dennis A. Rondinelli (1983) also mentioned the same thing. According to them, environmental condition variables greatly influence policy implementation. This variable has 7 (seven) indicators, namely: (i) type of political system, (ii) structure of policy making, (iii) 
characteristics of local political structures, (iv) resource constraints, (v) socio-cultural characteristics, (vi) degree involvement of program beneficiaries, and (vii) the availability of sufficient physical infrastructure.

From the various expert opinions above, we can once again see that the social environment receives its own attention in the implementation of a public policy. In this social environment, life in various local values is often referred to as social capital. Connecting the opinions of the experts above, we can say that the values of social capital have a very important influence on the successful implementation of a public policy.

\section{The Dark Side of Social Capital in the Implementation of Public Policy}

As a theory, social capital itself is very close to other social terminology as it is known as social virtue. The difference between the two lies in the dimensions of the network, where social virtue will be very strong and influential if there is an inherent feeling of attachment to mutual relations in a form of social relations (Hasbullah, 2006, p. 5-6). Putnam (2000, in Hasbullah, 2006, p. 6) provides propositions about community entities that have high social virtues, but at the same time related to social life, then community entities will connect community entities that have a low level of social wisdom. Thus, being able to participate with participation will grow well if there is social capital in the community, and community participation will be higher if social capital in the community is high. Vice versa.

One of the main figures who had a major influence in the development of thinking about social capital was James Samuel Coleman. ${ }^{10}$

\footnotetext{
${ }^{10}$ Yustika (2008, p. 178, in Kimbal, 2015, p. 19) suggests that Coleman was the first scientist to introduce social capital in English through an article published in 1988 in the American Journal of Sociology with the title "Social capital in the creation of human capital," after the idea of social capital was first introduced by Pierre Bourdie in 1970 through his writing entitled "Le capital Social:
}

Through his research on youth and education in schools in America, Coleman (1990, p. 302) defines social capital as a variant of an entity consisting of several social structures that facilitate the actions of the actors. Such actions can be in the form of personal or group, in a social structure. According to Coleman, social capital is inherent in the structure of relations between individuals.

Another idea of social capital was delivered by Adler and Kwon (2000, p. 92). According to them, social capital is a picture of the internal attachments that characterize the collective structure and provide cohesiveness and mutual benefits from the processes and dynamics of social capital contained in the intended structure.

As explained in the introduction to this paper, besides being proven to have a positive contribution, social capital also has the potential to contribute negatively to the implementation of development, in this case towards the implementation of poverty reduction policies. This research itself relies on the initial suspicion that cultural values as one dimension of social capital in society has the potential to become more exclusive, so that it has a negative impact on the implementation of poverty reduction policies that target community members who adhere to these cultural values as a group policy target.

\section{Case Study of the Tanimbar Islands Regency}

The Tanimbar Islands are one of the regencies in the Maluku Province that was formed in 1999. ${ }^{11}$ The establishment of the

\footnotetext{
Notes Povisoires". In contrast to Coleman's writings which immediately received a rousing welcome by social scientists, Bourdieu's article was written in French so that it did not receive sufficient attention at the time from social researchers.

${ }^{11}$ The Tanimbar Islands Regency was first formed under the name of West Southeast Maluku Regency based on Law Number 46 of 1999 concerning the Establishment of North Maluku Province, Buru Regency, and West Southeast Maluku Regency. The regulation on the formation of this regency was then amended by Law
} 
Tanimbar Islands as a new autonomous region was part of the implementation of extensive regional autonomy and reform in post-fall of the New Order regime.

Tanimbar Islands Regency is one of the island regencies with 81 islands, consisting of one large island, namely Yamdena Island, and 80 small islands. All the islands are known as the Tanimbar Islands cluster, of which 45 islands are inhabited and 36 islands are not inhabited (Central Statistics Agency of West Southeast Maluku Regency, 2018, p. 14). Of the total islands, Tanimbar Islands Regency has 4 outermost small islands, namely Asutubun Island, Selaru Island, Batarkusa Island, and Larat Island. ${ }^{12}$ The population of Tanimbar Islands Regency in 2017 was 123,831 people (data can be seen in Table 1$)^{13}$ with the population being more concentrated in small islands, also generally inhabiting coastal areas. Most of the population comes from Tanimbar ethnicity, while others come from various ethnicities or tribes in Indonesian regions such as Chinese, Kei, Aru, Ambon, Seram, Ternate, Kupang, Papua, Bugis, Buton, Makassar, Toraja, Manado, Java, Madura, Bali, Batak, Minang, Southwest Maluku, and so on.

\footnotetext{
No. 6/2000 concerning Amendments to Law No. 46/1999 concerning the Establishment of North Maluku Province, Buru Regency, and West Southeast Maluku Regency. The change in the name of this regency from West Southeast Maluku Regency to Tanimbar Islands Regency was only carried out in January 2019 through Government Regulation Number 2 of 2019 concerning Amendment to the Name of West Southeast Maluku Regency into Tanimbar Islands Regency in Maluku Province.

${ }^{12}$ The status of "Outermost Islands" in the Tanimbar Islands Regency is determined through Government Regulation No. 78/2005 concerning Management of Outermost Small Islands.

${ }^{13}$ The latest publication of the West Southeast Maluku Regency Statistics Agency in the book document West Southeast Maluku Regency in Figures 2018.
}

Table 1.

Population of Regency of Tanimbar Islands According to District and Gender in 2017

\begin{tabular}{ccccc}
\hline No & \multicolumn{1}{c}{ District } & Male & Female & Total \\
\hline (1) & $(2)$ & $(3)$ & $(4)$ & $(5)$ \\
1. & South Tanimbar & 18,310 & 17,766 & 36,076 \\
2. & Wertamrian & 5,856 & 5,862 & 11,719 \\
3. & Wermaktian & 6,865 & 6,631 & 13,496 \\
4. & Selaru & 7,153 & 6,916 & 14,096 \\
5. & North Tanimbar & 7,321 & 7,416 & 14,737 \\
6. & Yaru & 2,737 & 2,704 & 5,441 \\
7. & Wuarlabobar & 4,452 & 8,729 & 8,729 \\
8. & Nirunmas & 3,771 & 7,501 & 7,501 \\
9. & Kormomolin & 4,033 & 8,082 & 8,082 \\
10. & Molu Maru & 2,046 & 3,918 & 3,981 \\
\multicolumn{2}{c}{ Tanimbar Islands } & $\mathbf{6 2 , 5 4 4}$ & $\mathbf{6 1 , 2 8 6}$ & $\mathbf{1 2 3 , 8 3 1}$ \\
\hline
\end{tabular}

Source: Regency Statistics Center of Maluku Tenggara Barat (2018, p. 57).

When viewed from the potential of natural resources possessed, small islands in this area provide productive natural resources such as oil and gas $^{14}$, economically valuable timber ${ }^{15}$, coral reefs, seagrasses, mangrove forests, capture fisheries ${ }^{16}$, aquaculture ${ }^{17}$, and other marine products such as sea cucumbers, lola coral reef, fight stones, and japing. In addition, these small islands also provide conservation areas and provide large environmental services. Because of their natural beauty, they have the potential to drive the marine tourism industry.

By utilizing various potential resources owned, in the last twenty years, the Tanimbar Islands Regency Government has been trying

\footnotetext{
${ }^{14}$ Information about the potential of oil and gas found in this area can be examined including through Majalah Tempo, February 22 - March 6, 2016, p. 4, 27, 102, 104$106,108-113$. Also through exploration activities carried out by INPEX, CNOOC (China National Offshore Oil Corporation), and BP (British Petrolium) which can be checked on http://www.inpex.co.jp, http://www.cnooc. com.cn, and http://www.bp.com.

${ }^{15}$ Such linggua (pterocarpus indicus), torem (manilkara kanosiensis), merbau (intsia bijuga), kayu arang (dyospiros $s p$ ), and matoa (pommetia $s p$ ).

${ }^{16}$ Such as tuna, skipjack, komu, baronang, and grouper.

${ }^{17}$ Such as sea weed (eucheuma cottoni and eucheuma spinosium) and pearl.
} 
to carry out various development efforts to improve the welfare of its people. However, it turns out that this business has not produced significant results. On a provincial scale, the Tanimbar Islands Regency, in 2014, or at the time this research was conducted, ranked as the third poorest in 9 regencies and 2 cities in Maluku Province, after the West Seram and East Seram Regencies (data can be seen in Table 2).

Table 2.

Number of Poor Population in Maluku Province by Regency and City

\begin{tabular}{clc}
\hline No & \multicolumn{1}{c}{ Regency/City } & $\begin{array}{c}\text { Number of Poor } \\
\text { Population (000) }\end{array}$ \\
\hline (1) & \multicolumn{1}{c}{$(2)$} & $(3)$ \\
1. & Tanimbar Islands Regency & 35.8 \\
2. & Southeast Maluku Regency & 27.5 \\
3. & Central Maluku Regency & 29.6 \\
4. & Buru Regency & 18.7 \\
5. & Aru Islands Regency & 29.4 \\
6. & West Seram Regency & 102.8 \\
7. & East Seram Regency & 49.6 \\
8. & Southwest Maluku Regency & 31.2 \\
9. & South Buru Regency & 27 \\
10. & Ambon City & 11.7 \\
11. & Tual City & 25.5 \\
& Maluku Province & 389.1 \\
\hline
\end{tabular}

Source: Central Statistics Agency of Maluku Province (2019) ${ }^{18}$

The number of poor people in Tanimbar Islands Regency in March 2014, or in the year that was the focus of this study, was 35,800 people or around $39.5 \%$ of the total population. With this figure, the percentage of poor people in Tanimbar Islands Regency has doubled compared to the percentage of poor people in Maluku Province, which is as many as $19.13 \%{ }^{19}$ and almost four times compared to the percentage of poor people nationally, which is as many as $11.25 \% .{ }^{20}$

\footnotetext{
${ }^{18} \mathrm{https} / /$ maluku.bps.go.id.

${ }^{19}$ Maluku Provincial Statistics Agency (2014).

${ }^{20}$ Central Statistics Agency (2014).
}

To catch up the poverty that has plagued the community in Tanimbar Islands Regency (at that time, this area was still called West Southeast Maluku Regency), the regional government tried to improve various development policies. The effort is realized through a new paradigm of development carried out in 2012-2017, namely: "Realizing a Prosperous and Independent West Southeast Maluku Community through Inclusive and Sustainable Development." The main meaning contained in this vision is that all the wealth of natural resources possessed can be managed by the human resources of the Tanimbar Islands, so that this area can become a "comfortable home for everyone," as implied in the term "inclusive" in the vision statement above.

The vision was then translated into a mission: (i) realizing a society that has a diversification of business oriented to agribusiness and economic resilience with increasing and equitable income so as to be able to meet decent living needs, (ii) realizing the independence of the West Southeast Maluku community in the field of social, cultural, political, and government as social capital to develop into the future, (iii) realizing equitable development and the results of development to all regions and all levels of society, and (iv) realizing environmental sustainability to meet the future in front of the more advanced, sustainable and civil society of West Southeast Maluku. The four main missions above were then translated into various development policies, which essentially aimed to create a situation of prosperity for the entire Tanimbar community.

One of the development policies that became the focus of this study was poverty reduction policies implemented in Tanimbar Islands Regency in 2011 to 2015. Historically, this poverty reduction policy was derived from the Republic of Indonesia Presidential Regulation No. 15/ 2010 concerning the Acceleration of Poverty Reduction. This 
Presidential Regulation was then revealed to be a package of poverty reduction policies at the provincial, regency and city levels, which is referred to as the Regional Poverty Reduction Strategy. The Regional Poverty Reduction carried out in Tanimbar Islands Regency in 2011 to 2015 includes 4 (four) action plans, namely: (i) action plans in the field of poverty and employment, (ii) health action plans, (iii) education action plans, and (iv) action plans for basic infrastructure. Each of these action plans has a number of superior policies, programs and activities, whose implementation is managed by the relevant regional work unit.

When referring to statistical data published by the Central Statistics Agency after the implementation of this SPKD (publication data after 2015), at a glance the poverty reduction policies implemented in this area can be said to have experienced success. This can be seen in Graph 1, where data on the Human Development Index (HDI) in this regency experienced an increasing trend (escalation) in 2011 to 2015. In 2011, the Tanimbar Islands Regency HDI was at 57.69. This number increased in 2015 to 60.26 .

\section{Graph 1.}

Development of the Human Development Index in Tanimbar Islands Regency in 20112015

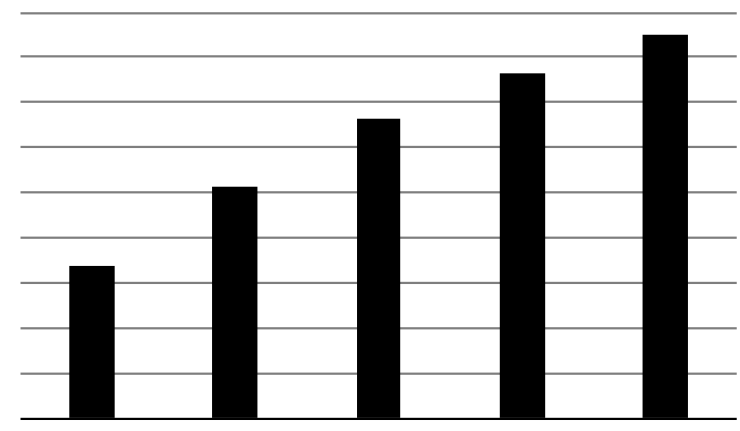

Source: West Southeast Maluku Regency Central Statistics Agency (2018)

However, in another section, data on the number of poor people in the Tanimbar Islands
Regency, as seen in Graph 2, experienced a fluctuating downward trend with a relatively small number, namely from the total population of 32,800 people in 2011 to 32,430 people in in 2015.

\section{Graph 2.}

Development of the Poor Population in Tanimbar Islands Regency in 2011-2015

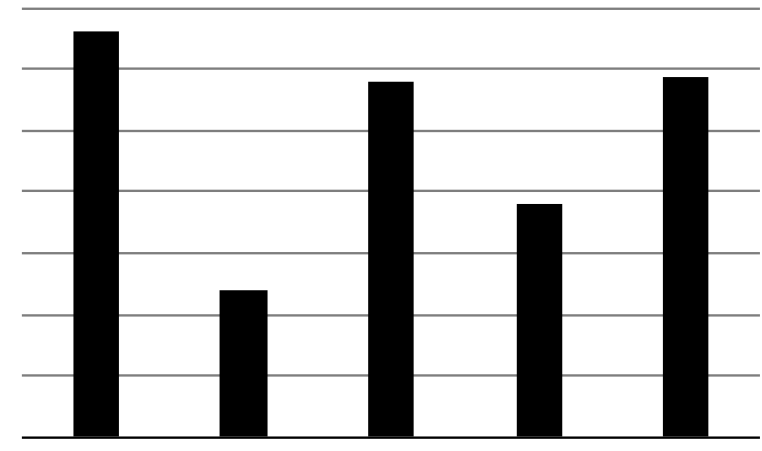

Source: Central Statistics Agency of West Southeast Maluku Regency (2018)

This situation causes, on a provincial scale (as seen in Graph 3), the Tanimbar Islands Regency still occupies the third-poorest position. This rating has not shifted since 2010.

Not only that, in 2015, Central Statistic Agency of Maluku Province placed the Tanimbar Islands Regency as the poorest region in Maluku Province in terms of accessibility (Ambon Ekspres, 2015; Dhara Pos, 2015). In fact, various poverty reduction programs and activities are basically aimed at freeing the poor from poverty by providing access to these poor people. Thus, it can be concluded that poverty reduction policies manifested in the form of Regional Poverty Reduction Strategy carried out in the Tanimbar Islands Regency from 2011 to 2015 did not fully experience success. There are a number of inefficiencies (relative failures) experienced by this policy.

As stated above, this research focuses on the connection between the existing conditions of duan lolat's values, sweri practices, 


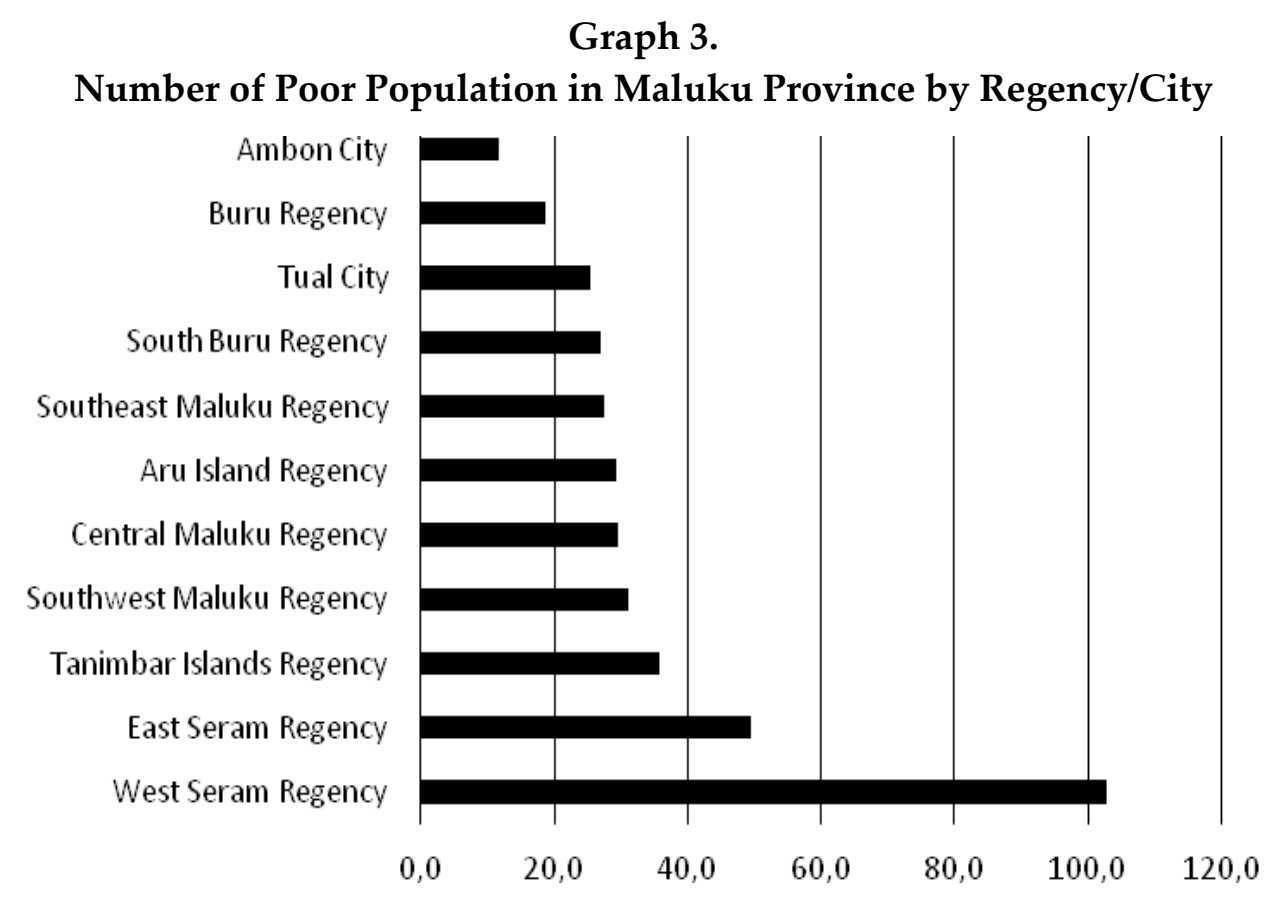

Source: Central Statistics Agency of Maluku Province (2019) ${ }^{21}$

and communal patterns of life in tnyafar as manifestations of social capital, with the ineffectiveness of implementing public policies (ineffectiveness in implementing poverty reduction policies) in this region.

\section{Existing Condition of Duan Lolat's Value: Exclusivism Phenomenon ${ }^{22}$}

Literally, using the East Yamdena Language ${ }^{23}$, the word duan means the master or owner of an item. This master or owner functions as a protector of the item. Meanwhile, lolat is the recipient of an item. In a traditional marriage, duan is a family group that acts as a

\footnotetext{
${ }^{21}$ https://maluku.bps.go.id.

${ }^{22}$ The data and information displayed in this section are the results of field observations conducted by the First Author.

${ }^{23}$ The Tanimbar indigenous people have 5 (five) regional languages, namely: (i) East Yamdena Language, (ii) Selaru Language, (iii) Seira, Larat, Fordata Language, (iv) Selwasa Language, and (v) Makatian Language. The East Yamdena language is the regional language adopted by most people in this area. It is referred to as the East Yamdena Language because this language is used by people who occupy areas along the east coast of Yamdena Island.
}

female giver. Meanwhile, lolat is a family group that acts as a female recipient. The kinship relationship is symbolized in various gifts, both from the duan and from the lolat party which takes place in a manner in every event of the life of the Tanimbar community, such as birth, marriage, building a house, and even death.

The duan party is usually obliged to provide clothes and equipment, including food ingredients in the form of rice and tubers, to the lolat party. Meanwhile, the lolat party was obliged to provide side dishes such as meat and drink sopi (Tanimbar's typical palm wine drink) to the duan party. Goods given, whether by duan or lolat, can also be in the form of customary objects such as woven fabrics, jewelry, elephant ivory, etc., which are adapted to the life events that are being faced. As time went on, the shape of the gift item also experienced various variations. At present, it is not uncommon for goods to be provided to be sufficiently converted in the form of money. ${ }^{24}$

\footnotetext{
${ }^{24}$ Regarding the relationship between Duan Lolat can be examined further on Koritelu (2009) Lerebulan (2011), and Wuritimur (2012).
} 
In social science studies, sociologists call kinship relations like this a kinship relationship driven by mechanical solidarity, in which a community will move mechanically to provide assistance when there are certain events that afflict one member of the community, both grief and happy events. Tönnies (1963) calls this society a society of gemeinschaft or kinship society, which is oriented towards the values of family ties, customs and religion within their social environment.

The value of Duan Lolat actually has such a noble purpose, as constructed by the ancestors of the Tanimbar community. In Duan Lolat's values, there is a spirit of mutual cooperation that is owned by every citizen. However, at present, the value of Duan Lolat has far deviated from its true meaning. For the sake of prestige and honor in the eyes of culture, many families are willing to sacrifice their basic needs, such as children's education or health, only to pay for the traditional dependents charged to them. The more indigenous relationships that are owned by a family, by marriage or other processes, the more the burden of the family must bear the custom.

\section{Sweri Practice ${ }^{25}$}

Another thing that is practiced by the Tanimbar community is sweri. Literally, using the East Yamdena language, sweri can be interpreted as a prohibition on not continuing an activity, which is symbolized by the installation of coconut leaf at the location where the activity is taking place temporarily. In the past, sweri was used to signify warnings (prohibitions) to local communities not to carry out activities in agricultural areas, plantations, or also the prohibition of not going to sea. This is done when agricultural and plantation products or sea yields are felt to experience a significant decline.

\footnotetext{
${ }^{25}$ The data and information displayed in this section are the results of field observations conducted by the First Author.
}

In addition, sweri also functions as a prohibition against damaging forest areas or beaches. This prohibition is valid for a certain period of time, adjusted to the "level of damage" that occurs in the area to which the sweri activity is to be carried out (generally the sweri is enforced for about six months). As a customary instrument, sweri activities are trusted by the local community loaded with various mystical contents, so that anyone who commits an offense against the sweri is believed to get a plague. Traditional sanctions in the form of plagues are believed to originate from God (Ratu Mangkuase) and ancestors (empunlusin) of the Tanimbar people. However, in an ecological perspective, we can interpret it as a traditional instrument of the Tanimbar community, which is used for the purpose of going green. In its development, nowadays, sweri is widely used to sue the land ownership status, when the owners of customary rights (local residents) feel that there are still issues of land ownership that have not been resolved between them and other parties who want to occupy or carry out activities on the land. Commonly, they ask for a large fee for the land that was sued.

This sweri practice not only takes place between citizens, but also between residents and the local government who want to do land acquisition for the construction of various public infrastructure. It may include health and education facilities. They are actually intended for the interests of the wider community, including community owners of customary rights.

\section{Communal Lifestyle in Tnyafar ${ }^{26}$}

Another habitus practiced by some Tanimbar communities is a communal lifestyle in tnyafar. ${ }^{27}$ Literally, using the East Yamdena language, tnyafar can be called a village in the plantation area. Some communities in the Tanimbar Islands chose not to settle in their

\footnotetext{
${ }^{26}$ The data and information displayed in this section are the results of field observations and interviews conducted by the First Author.

${ }^{27}$ Results of field data collection.
} 
Table 3.

List of named and populations of Tnyafar in Adaut Village

\begin{tabular}{|c|c|c|c|}
\hline No. & Name of Tnyafar & Head name of Tnyafar & Population \\
\hline 1. & Bwariat Lafesi & Hofni Nanariain & 78 \\
\hline 2. & Kelibait & Yohanis Sainfalak & 180 \\
\hline 3. & Alsar & Yermias Sikafir & 123 \\
\hline 4. & Bunga Tanjung & Yohanis Ngilamele & 315 \\
\hline 5. & Rumah Tiga & Zefnat Lerebulan & 45 \\
\hline 6. & Lende Jaya & Hans Ngilamele & 425 \\
\hline 7. & Batfyalu & Nikolas Batfeni & 98 \\
\hline 8. & Timrar & Alfaris Fenanlambir & 54 \\
\hline 9. & Weyematan Silai & Ridolof Kotngoran & 275 \\
\hline 10. & Torintubun Silai / TTS & Edi Lorwens & 107 \\
\hline 11. & Torintubun Marumat / TTM & Natanyel Batlayar & 98 \\
\hline 12. & Nifmas & Agustinus Angwarmasse & 215 \\
\hline 13. & Wetyayan & Ruben Matkusa & 179 \\
\hline 14. & Nuyanat Timur & Kadio Lerebulan & 49 \\
\hline 15. & Nuyanat Barat & Abraham Naranmase & 56 \\
\hline 16. & Minanlel & Alexander Boruthnaban & 135 \\
\hline 17. & Namar & Yusuf Maskikit & 98 \\
\hline 18. & Werndulan & Natanyel Matweru & 28 \\
\hline 19. & Adautubun / Paris & Ruben Melsasail & 171 \\
\hline 20. & Weyedas & Yulianus Ratuanak & 43 \\
\hline 21. & Totoblain & Yakop Lerebulan & 25 \\
\hline 22. & Yerun & Ales Fadirsair & 35 \\
\hline 23. & Kaubar Sepan & Daniel Rangratu & 26 \\
\hline 24. & Bulurtubun / Tnyetak & Yakonias Laratmasse & 42 \\
\hline 25. & Weyematan & Daniel Lethulur & 31 \\
\hline 26. & Tburi Indah & Martinus Batlayeri & 53 \\
\hline 27. & Tburi Exa & Melkianus Batjeran & 45 \\
\hline 28. & Lunar Kait / Arwean & Kristofol Sabarlele & 64 \\
\hline 29. & Timur Silai / Roma & Ganefo Fendjalang & 48 \\
\hline 30. & Wesoan & Theo Uwuratuw & 33 \\
\hline 31. & Fulmaman & Yusuf Fambrene & 29 \\
\hline 32. & Tongarlos / Jakarta Dua & Melkianus Titirlolobi & 27 \\
\hline 33. & Kora Atas & Simon Matkussa & 58 \\
\hline 34. & Kora Bawah & Magalhein Yempormase & 42 \\
\hline 35. & Manaketa & Melkianus Baresaby & 28 \\
\hline 36. & Wesori & Darmo Fambrene & 31 \\
\hline 37. & Ebwar Jaya & Beni Nanariain & 18 \\
\hline 38. & Waimbyari & Efen Yempormase & 32 \\
\hline \multicolumn{3}{|c|}{ Total Population } & 3.439 \\
\hline
\end{tabular}

Sumber: Adaut Village Government (2018)28

villages, but they then settled in the plantation for a long time to do gardening activities and plant crops. In Adaut Village, which is one of the locations of this study, there are 38 (thirty eight) tnyafar, with the population as shown in Table 3.

\footnotetext{
${ }^{28}$ Results of field data collection.
}

According to the local community, by staying in the area, it will be more effective and efficient. It is because their farming systems are shifting fields so the distance between gardens or fields with settlements, or settlements in rural areas, is relatively considered far enough. This condition is exacerbated by the absence of road access that connects their settlements to 
the plantation area, if they have to settle in the village. Meanwhile every day they have to work in fields or gardens, it will take considerable time and energy. With that in mind, they chose to stay and settle in the area of tnyafar. Another reason why residents choose to live in tnyafar is as a form of their affirmation that the land is a land that is culturally controlled and owned by ancestors, villages, and / or their clans, and passed down from generation to generation. This is in accordance with the statement of one of the residents of Adaut Village who lives in tnyafar, as follows:

"Tnyafar ini katong pung moyangmoyang punya yang dong wariskan turun-temurun ke katong. Karena itu, katong harus tinggal di tnyafar ini par jaga akang. (Tnyafar is the property of our ancestors who have been passed down from generation to generation. Therefore, as heirs we have to live in tnyafar)." (Interview, 7 December 2017).

The tnyafar location is not concentrated at one point but spreads at several points. The location of tnyafar can also be on a different island from the island where they live. One village, for example, can have more than one tnyafar. In fact, on average, each village can have up to ten tnyafar. One tnyafar can be occupied by about a dozen family heads. They made garden houses in one location, and in the area they occupied, they then planted gardens. The same situation also occurs in other fields.

Social problems began to emerge when the community living in this area was faced with problematic situations in the fields of health and education. Most drop-out rates occur in villages where the majority of the population lives in tnyafar area, and so are health problems. With the condition of the village that spreads like this other community, the local government will have difficulty accessing these locations to provide education and health services. As a result, the people living in the area also cannot access education and health services organized by the government. This is a problematic situation that needs immediate solutions.

\section{Conclusion}

The study of the paradox of social capital in relation to the implementation of poverty reduction policies in Tanimbar Islands Regency is a piece of mosaic from the blurred portrait of ineffectiveness to the failure of the implementation of a public policy that occurs in Indonesia caused by a phenomenon that occurs in our social capital called the dark side social capital. In the future, every stakeholder needs to continue to improve its value, so that value as one of the dimensions of social capital that has been rooted in society so far can be managed productively. This effort is important, so that social capital can support the implementation of development through the implementation of various public policies that are actually aimed at creating independence and prosperity for the community.

On the other hand, we need to interpret the various loopholes in social capital as part of the process of transitioning this nation to a more substantive democratic life, after all this time we have been in the hegemony of the New Order regime. In the post-reform era, serious improvements need to be made to our public bureaucratic body, which so far is still too focused on working on less strategic things (Pramusinto, 2016, p. 7). ${ }^{29}$ This is because the public bureaucratic institutions are in fact the main drivers of the development wheel through the formulation and implementation of various public policies. In the perspective of public policy, a more substantive democratic life can be achieved through a just public policy approach that can respond (treat) cultural values in our society more adequately and proportionally.

\footnotetext{
${ }^{29}$ Pramusinto further explained that bureaucratic reform has so far been too focused on serving the internal interests of the bureaucracy and has been trapped in work that is merely formalism.
} 


\section{References}

Adler, P., \& Kwon, S. (2000). Social capital: The good, the bad and the ugly. In E. Lesser (Ed.), Knowledge and social capital: Foundations and applications (pp. 89-118). USA: Butterworth-Heinemann.

Ambon Ekspres. (2015). MTB termiskin di Maluku. Retrieved March 20, 2018, from http:// ambonekspres.fajar.co.id/2015/02/24/ mtb-termiskin-di-maluku/.

Anderson, J. E. (1990). Public policymaking: An introduction. Boston: Houghton Mifflin.

Asmara, H.M. G., Arba, \& Maladi, Y. (2010). Penyelesaian konfik pertanahan berbasis nilai-nilai kearifan lokal di Nusa Tenggara Barat, Jurnal Mimbar Hukum Universitas Gadjah Mada, 22(1).

Badan Pusat Statistik Kabupaten Maluku Tenggara Barat. (2018). Maluku Tenggara Barat dalam angka 2018. Saumlaki: Badan Pusat Statistik Kabupaten Maluku Tenggara Barat.

Center for Strategic and International Studies. (2017). Demand Driven Development. Retrieved May 1, 2018, from https:// www.csis.org/events/demand-drivendevelopment.

Central Statistics Agency of Maluku Province. (2014). Official News Statistics No.07/01/81/ Th. XVI, July 1 2014. Retrieved July 9, 2018, from http://www.maluku.bps.go.id.

Cheema, G. S., \& Rondinelli, D. A. (1983). Decentralization and development: Policy implementation in developing countries. Beverly Hills: Sage Publications.

Coleman, J. (1990). Foundation of social theory. Cambridge: Harvard University Press.

Dhara Pos. (2015). Termiskin di Maluku, Bupati MTB didesak evaluasi pimpinan SKPD. Retrieved March 20, 2018, from http:// www.dharapos.com/2015/04/termiskindi-maluku-bupati-mtb-didesak.html.

Edwards III, G. C. (1980). Implementing public policy. Washington: Congressional Quarterly Press.
Geertz, C. (1989). Penjaja dan Raja: Perubahan sosial dan modernisasi ekonomi di dua kota Indonesia. Jakarta: Yayasan Obor Indonesia.

Government Regulation of the Republic of Indonesia No. 15/2010

Government Regulation of the Republic of Indonesia No. 2/2019

Government Regulation of the Republic of Indonesia No. 78/2005

Graeff, P. 2009. "Social Capital: The Dark Side" in Svendsen, Gert Tinggaard - Haase Svendsen, Gunnar Lind (Eds.). "Handbook of Social Capital". Cheltenham: Edward Elgar Publishing.

Grindle, M. S. (1980). Politics and policy implementation in the Third World. New Jersey: Princenton University Press.

Hasbullah J. (2006). Social Capital (Menuju Keunggulan Budaya Manusia Indonesia). Jakarta: MR-United Press.

Kimbal, R. W. (2015). Modal Sosial dan Ekonomi Industri Kecil: Sebuah Studi Kualitatif. Yogyakarta: Deepublish.

Kusumasari, B. (2014). Manajemen bencana dan kapabilitas pemerintah lokal. Yogyakarta: Gava Media.

Koritelu, P. (2009). Perubahan Hubungan Sosial Duan dan Lolat di Olilit Raya, Tanimbar, MTB, dalam Kurun Waktu 19952004. (Doctoral dissertation Universitas Indonesia, 2009). Depok, Indonesia: Universitas Indonesia.

Lerebulan, A. (2011). Tanimbar, Kepulauan Tanimbar: antara Tradisi dan Kehidupan Modern. Yogyakarta: Kanisius.

Litvack, J., Ahmad, J., \& Bird, R. (1998). Rethinking decentralization in developing countries. Washington DC. The World Bank.

Margono, S. A., \& Kusumasari, B. (2014). Manajemen Publik Kontemporer. Yogyakarta: Gava Media.

Mazmanian, D. A., \& Sabatier, P. A. (1983). Implementation and public policy. Scott, New Jersey: Foresman and Company. 
Mulyadi. (2010). Pengaruh modal sosial, locus of control, dan motivasi terhadap perilaku berwawasan lingkungan petani dalam mengelola lahan pertanian di Kabupaten Soppeng. Jurnal Manusia dan Lingkungan, 18(1).

Nurhadi. (2000). Modal sosial dalam pengembangan hutan rakyat: Studi kasus Desa Kedungkeris, Kecamatan Ngipar, Kabupaten Gunung Kidul. Jurnal Hutan Rakyat, 2(1).

Pramusinto, A. (2016). Mendorong Perubahan dari Luar: Ke Arah Birokrasi Indonesia yang Demokratis dan Melayani. Speech presented at Inauguration of Professors at the Faculty of Social and Political Sciences of Universitas Gadjah Mada, in Yogyakarta, Indonesia.

Ruslanjari, D. (2010). Peran Kearifan Lokal dalam Kecepatan Rehabilitasi dan Rekonstruksi Bencana Gempa Bumi di Desa Multireligi dan Monoreligi: Kasus di Kabupaten Bantul. Jurnal Kebencanaan, 2(3).

Sahlan. (2009). Partisipasi masyarakat Wana (Tau Taa Wana Bulang) dalam mengkonservasi hutan berdasar kearifan lokal di Propinsi Selawesi Tengah. (Doctoral dissertation Universitas Gadjah Mada, 2009). Yogyakarta, Indonesia: Universitas Gadjah Mada.

Senoaji. (2004). Pemanfaatan hutan dan lingkungan oleh masyarakat Baduy di Banten Selatan. Jurnal Manusia dan Lingkungan, XI(3). Yogyakarta: Pusat Studi Lingkungan Hidup, Universitas Gadjah Mada.

Sulastriyono. (2008). Pembangunan hukum sumber daya air sungai yang berbasis modal sosial: Peluang dan tantangannya. Jurnal Mimbar Hukum Universitas Gadjah Mada, 20(3).

Sulastriyono. (2009). Nilai-nilai modal sosial dalam pengelolaan sumber daya air di
Telaga Omang dan Ngloro, Kecamatan Saptosari, Gunung Kidul, Yogyakarta. Jurnal Mimbar Hukum Universitas Gadjah Mada, 21(2).

Susanto, E., \& Rostiani, R. (2012). Enhancing cross cultural training efficacy on expatriate adjustment through emotional intelligence and social capital. Gadjah Mada International Journal of Business, 14(2), 1-16.

The Constitution of the Republic of Indonesia No. 32/2004

The Constitution of the Republic of Indonesia No. 46/ 1999

The Constitution of the Republic of Indonesia No. $6 / 2000$

The Constitution of the Republic of Indonesia No. $12 / 2008$

The Constitution of the Republic of Indonesia No. 22/ 1999

The Constitution of the Republic of Indonesia No. 23/ 2014

The Constitution of the Republic of Indonesia No. $8 / 2005$

Tönnies, F. (1963). Community and society. (C. P. Loomis, Trans.). New York: Harper and Row.

van Meter, D. S., \& van Horn, C. E. (1975). The policy implementation process: A conceptual framework. Administration and Society, 6(4).

World Bank. (1998). The initiative on defining, monitoring and measuring social capital: Text of proposal approved for funding. Social Capital Initiative Working Paper No.2. The World Bank: Social Development Family, Environmentally and Socially Sustainable Development Network.

World Bank. (2006). Social Capital in Economic Trade and Migration.

Wuritimur, A. (2012). Basudara orang Tanimbar: Model kearifan lokal. Yogyakarta: Kanisius. www.mtbkab.go.id 